\title{
Epilepsy: Relationships Between Electrophysiology and Intracellular Mechanisms Involving Second Messengers and Gene Expression
}

\author{
P. Gloor
}

\begin{abstract}
It is well known that pure absence epilepsy is a benign form of seizure disorder, while most others, particularly partial and convulsive seizures may have transient or permanent deleterious consequences and are more difficult to bring under therapeutic control by anticonvulsants. The hypothesis is proposed that the preservation of GABAergic inhibition in absence attacks and its breakdown in most other seizures may explain these differences. Breakdown of GABA-ergic inhibition allows NMDA receptors to become active. This opens the way for $\mathrm{Ca}^{2+}$ to enter the cell. Such $\mathrm{Ca}^{2+}$ entry is a long-lasting phenomenon. It is likely to be massive during most seizures except during absence attacks, and may therefore damage the neuron transiently or permanently. It may even destroy it. $\mathrm{Ca}^{2+}$ entry is also a crucial factor in the activation of the second messenger cascade which involves cytosolic as well as nuclear (genomic) components. Activation of this cascade converts short-lived electrophysiological processes occurring at the membrane into much longer-lasting intracellular processes. These may include plastic changes at the synaptic and receptor level and may account for kindling and the increasing therapy-resistance of long-standing seizure disorders. Changes resulting from massive $\mathrm{Ca}^{2+}$ entry into the neuron may explain why most seizures, except absence attacks, may have deleterious consequences of various kinds, some short-lived, some of longer duration, and some even permanent.
\end{abstract}

\begin{abstract}
RÉSUMÉ: Epilepsie: relations entre l’électrophysiologie et mécanismes intracellulaires impliquant messagers secondaires et expression génétique Le fait que les crises d'absences pures représentent une forme d'épilepsie qui est bénigne, tandis que la plupart des autres formes, particulièrement celles avec crises partielles et convulsives, sont portées à être suivies de déficits postcritiques transitoires ou permanents, est bien connu. Les crises partielles et convulsives sont aussi connues pour être plus rebelles aux traitements médicamenteux que les crises d'absences. Une hypothèse est proposée selon laquelle ces différences découleraient du fait que l'inhibition GABA-ergique est préservée dans les crises d'absence, tandis qu'elles s'effondre dans la plupart des autres crises. L'effondrement de l'inhibition GABA-ergique permet l'activation des récepteurs NMDA, ce qui rend possible la pénétration du Ca ${ }^{2+}$ dans la cellule. L'augmentation du taux de $\mathrm{Ca}^{2+}$ intracellulaire est un processus de longue durée. Il est probable que l'influx de $\mathrm{Ca}^{2+}$ dans le neurone est massif au cours de la plupart des crises, sauf dans les crises d'absence. Cette pénétration massive du $\mathrm{Ca}^{2+}$ peut léser le neurone de façon transitoire ou permanente, elle peut même le détruire. L'entrée du Ca ${ }^{2+}$ dans la cellule en plus est un facteur crucial pour mettre en marche la cascade des messagers secondaires. Celle-ci met à contribution des composantes cytosoliques ainsi que nucléaires (impliquant le génome). L'activation de cette cascade transforme les processus électrophysiologiques de brève durée qui se déroulent sur la membrane en processus intracellulaires beaucoup plus prolongés. Parmi ceux-ci l'on peut citer des altérations plastiques au niveau des synapses et des récepteurs. Des processus de ce genre sont vraisemblablement impliqués dans le phénomène du "kindling" et pourraient expliquer la résistance croissante aux traitements médicamentaux dans le cas de crises qui continuent à se répéter. Les altérations induites par l'influx massif du $\mathrm{Ca}^{2+}$ dans le neurone pourrait expliquer pourquoi la plupart des crises épileptiques, excepté les absences, sont portées à engendrer de diverses séquelles postcritiques déficitaires, dont certaines sont de brève durée, d'autres plus prolongées et d'aucunes même permanentes.
\end{abstract}

Can. J. Neurol. Sci. 1989; 16:8-21

From the Department of Neurology and Neurosurgery of McGill University and the Montreal Neurological Institute

A shorter version of this paper was presented at the XXIII Canadian Congress of Neurological Sciences on June 16, 1988 in Quebec City. Dr. Gloor was the special guest lecturer of the Canadian Society of Clinical Neurophysiologists.

Reprint requests to: Dr. P. Gloor, Montreal Neurological Institute, 3801 University St., Montreal, Quebec, Canada H3A 2B4 
The consequences of epileptic seizures vary according to the type of epilepsy. This fact is one of the arguments which contributed to the notion that there are "functional" and "organic" seizure disorders. ${ }^{1}$ The issue of what determines the occurrence of deleterious consequences of some seizures and why they are missing in others is still unclear and controversial. This paper examines the proposition that seizures by themselves in some instances play a pathogenetic role in epilepsy, and represent a factor which contributes to render certain seizure disorders less benign than others.

Most epileptologists would agree that absence epilepsy is one of the most benign forms of seizure disorders. 2,3,4.5,6.7 There are a number of arguments which support this view. In most patients with absence epilepsy the only signs of disturbance of neurological or intellectual function can be detected during an attack. There are in this disorder no short-term or long-term postictal neurological deficits. Postictal brain damage does not occur, even after absence status. The condition commonly remits in adolescence, particularly if there is no significant incidence of convulsive seizures, in which case the remission rate is considerably less. $3,4,7,8,9$

The hypothesis proposed in this paper is that absence epilepsy is benign in comparison to partial or generalized convulsive epilepsy, because GABA-ergic postsynaptic inhibition is fully preserved in spike and wave discharge as opposed to most other seizure patterns. $10,11,12,13,14,15,16$
Some of the differences that exist between absence attacks and other seizures are evident from the comparison of the EEG manifestations. In absence attacks, although the EEG manifestations are dramatic, they are non-evolving, the pattern remaining stable throughout the seizure and the end of the attack is not followed by any postictal clinical or electrographic depression (Figure 1A). By contrast partial or generalized convulsive seizures show an evolution of the EEG pattern in time with changes in the frequency of the discharge, and in the case of partial seizures, spatial spread (Figure 2). After its cessation, the seizure is followed by postictal slow-wave activity of variable duration (Figure 2) which is usually associated with clinical postictal disturbances (confusion, Todd's paralysis, etc.). Somewhat more controversial is the notion that some partial or convulsive seizures may lead to more enduring deleterious effects such as progressive memory deterioration and in some cases permanent brain damage. ${ }^{17,18,19,20,21}$ None of these consequences have ever been observed as consequences of absence seizures.

Experimental work both on models of absence and partial or convulsive seizures have yielded evidence that mechanisms in the two forms of seizure disorders differ. ${ }^{10.16}$ These differences may not only explain why the two seizure patterns differ, but more specifically may also account for the benign nature of absence attacks and for the frequent presence of more serious problems in the case of partial or convulsive seizures. One of

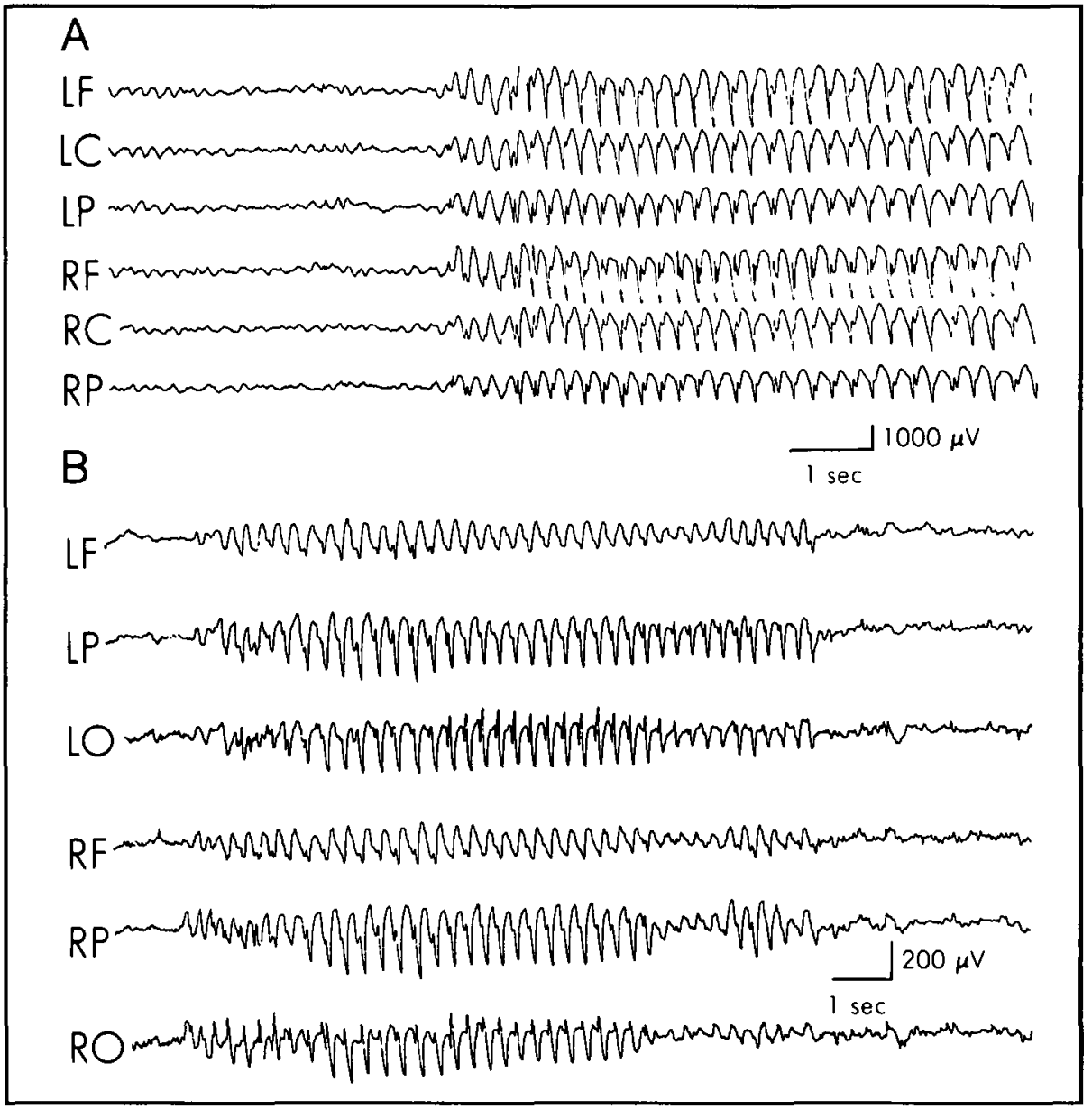

Figure I-Generalized spike and wave discharge $(A)$ in a 9-year-old boy during an absence attack, and $(B)$ in a cat having received a large dose of intramuscular penicillin. Note the similarity of the EEG patterns in man and cat, which is mirrored by concomitant behavioral manifestations. $L$ : left; $R$ : right; $F$ : frontal; $C$ : central; $P$ : parietal: $O$ : occipital. Note lack of evolution over time; no postictal changes. (A. From Gloor and Fariello 16, B. from Guberman et $a^{26}$ ). 
A

Cz-C3 3

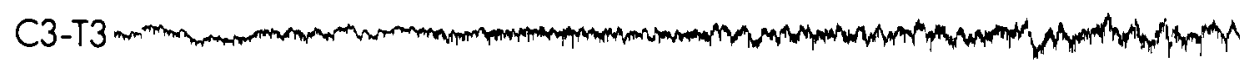

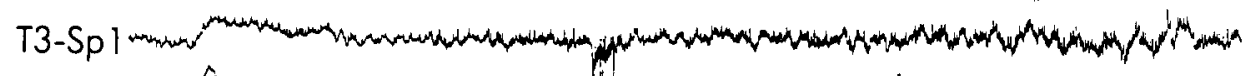

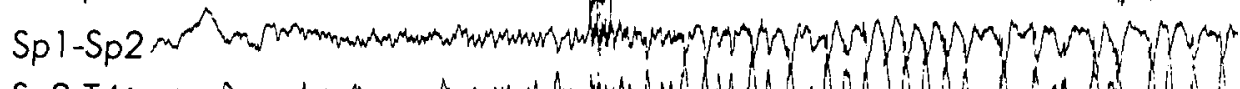

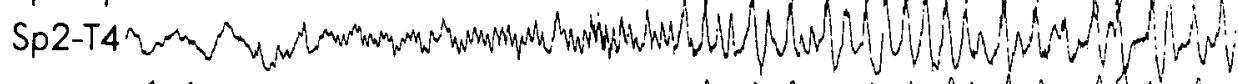

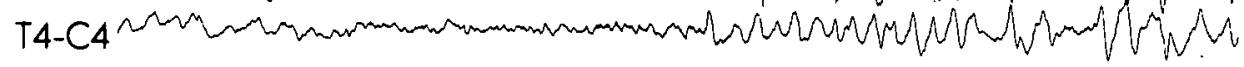

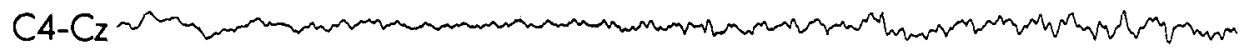
FP I-F3 C3-P3 3 -

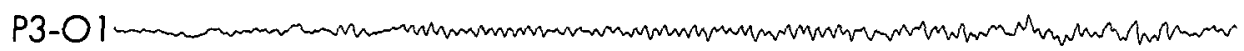
C4-P4 402-F4

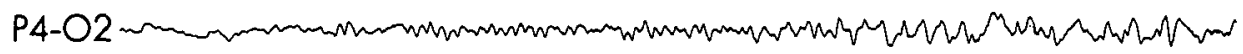

B

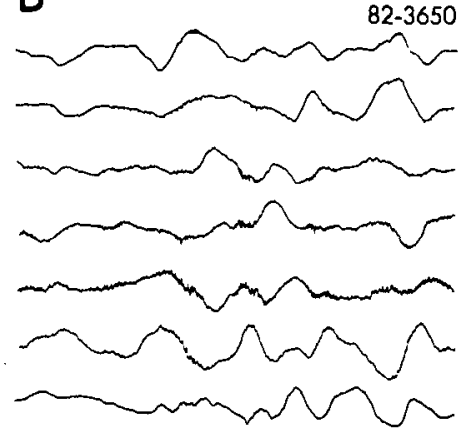

$1 \frac{1}{2}$ min. after end of seizure

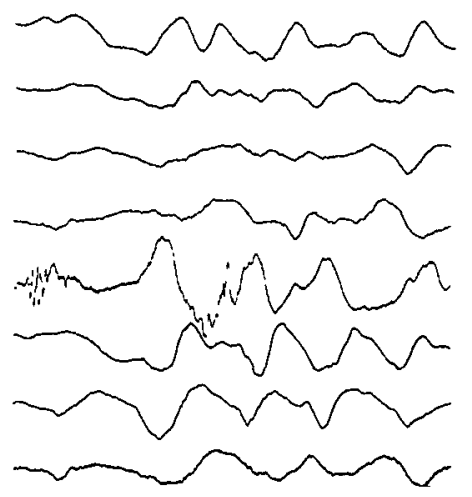

Figure 2-EEG record of a partial seizure. A: Seizure onset: note gradual evolution of seizure pattern: change in frequency and spatial spread. B: Postictal depression with slow waves. Electrodes are labeled according to 10-20 system (Sp: sphenoidal electrodes).

these problems is the relatively frequent refractoriness to therapy, ${ }^{7}$ and the lower incidence of spontaneous remission which possibly represents in part a consequence of repeated partial or convulsive seizures, a concept first enunciated more than a century ago by Gowers ${ }^{22}$ and for which some supportive evidence has recently been obtained. ${ }^{23,24}$

\section{Cellular Mechanisms of Absence Seizures}

The best model for studying the underlying mechanism of absence attacks is feline generalized penicillin epilepsy (FGPE). ${ }^{11,16}$ The EEG pattern in this condition is very similar to that seen during human absence attacks (Figure 1B) and so are the behavioral manifestations. ${ }^{25}$ Thus, in FGPE, cats fail to respond to a stimulus to which they have learned to respond, when that stimulus occurs during a spike and wave burst, but they respond normally to it, if it occurs between spike and wave bursts. There are other similarities between the human and the feline conditions, such as the overt minor motor manifestations consisting of eye blinking, sometimes associated with myoclonic jerks. Finally, FGPE responds to anti-absence drugs, but responds only erratically to phenytoin. ${ }^{26,27}$

Research in our laboratory has shown that spike and wave discharge in FGPE evolves from a modification of spindles which are the expression of a physiological thalamocortical interaction. ${ }^{11,16,28,29,30}$ Details of these mechanisms will not be discussed here, but what is important are the cellular microphysiological concomitants of the EEG spike and wave discharge. During such a discharge there occurs a striking oscilla- tion in the firing of single cortical and thalamic neurons, the cells showing a markedly increased firing probability during the spike phase and an almost total arrest of firing during the slow wave phase (Figure 3). ${ }^{11,16,29,31}$ We have hypothesized that this pattern expresses activation and intense recruitment of the intracortical recurrent inhibitory pathway into the discharge process. ${ }^{10,11,12,16}$ This activation appears to be a consequence of the increased firing of cortical neurons which occurs in a tightly synchronized phase-locked manner during the EEG spike discharge. This results in maximum stimulation of the inhibitory interneuron as it is subjected to highly effective spatial and temporal summation.

Since it is commonly assumed that the epileptogenic action of penicillin is solely explained by its antagonistic action on GABA-ergic postsynaptic inhibition, $32,33,34,35,36,37$ this hypothesis concerning the mechanism of spike and wave discharge may at first glance appear unconvincing. However, we have been able to demonstrate that with the low tissue concentrations of penicillin after its intramuscular injection that are present in the brain in FGPE, ${ }^{38}$ classical postsynaptic inhibition is preserved both when studied extra- and intracellularly (Figures 3B, C and 4A). ${ }^{12,13,15}$ The conclusive proof that such inhibition is indeed preserved under conditions in which spike and wave discharge occurs is shown by the observation that recurrent and direct cortical inhibition under these conditions, when studied intracellularly, satisfies all the criteria for classic postsynaptic inhibition. ${ }^{15}$ Thus the hyperpolarization in the early phase of inhibition is reversed by intracellular iontophoresis of $\mathrm{Cl}^{-}$ 
while the late $\mathrm{K}^{+}$mediated phase remains unaltered (Figure $4 \mathrm{~A})$. Intracellular recordings during spike and wave discharge show that the action potentials discharged during the spike

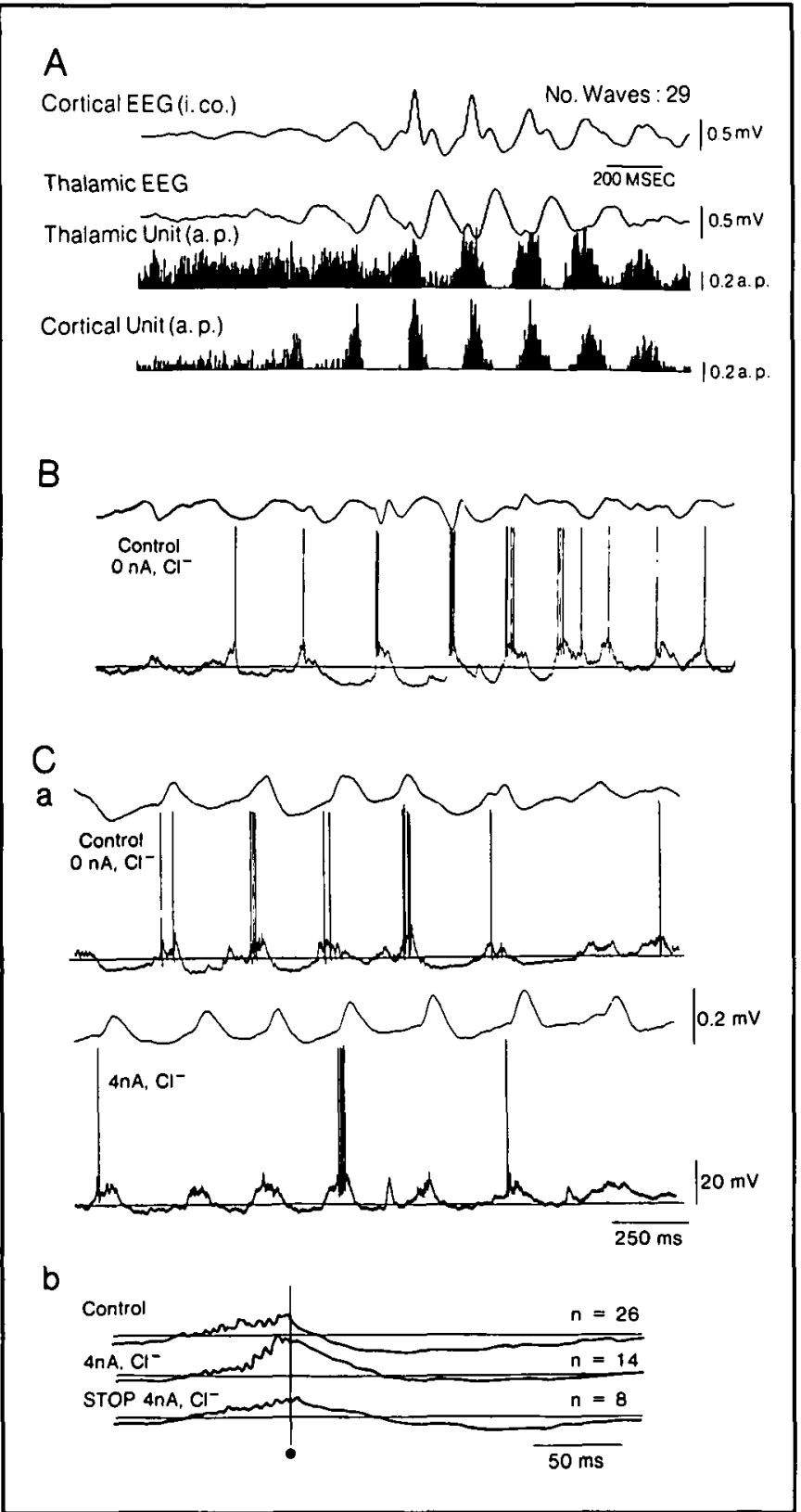

phase of the spike and wave complex occur on the top of a large excitatory postsynaptic potential (EPSP), while the arrest of action potential discharge is associated with hyperpolarization of the membrane (Figure 3B). This hyperpolarization, just as that of recurrent and direct cortical inhibition, is $\mathrm{Cl}^{-}$- sensitive in its early phase and therefore satisfies the criteria of classical postsynaptic inhibition (Figure 3C). The burst of action potentials which ride on the EPSP are all of equal amplitude and of short duration and therefore appear to be mediated by $\mathrm{Na}^{+}$with no evidence suggesting that $\mathrm{Ca}^{2+}-$ mediated action potentials occur. Finally, it has been shown that during spike and wave discharge the GABA sensitivity of cortical neurons is fully preserved and unaltered in comparison with that seen in the normal animal (Figure 4B). ${ }^{14}$

It is thus evident that during generalized spike and wave discharge in FGPE classical postsynaptic inhibition which is GABA mediated and exerted at the soma appears fully preserved ${ }^{16}$ and we may therefore surmise that the same is true for spike and wave discharge in human absence seizures.

However, there are conditions under which inhibition does break down in FGPE. In this condition, just as in patients with human absence attacks, convulsive seizures sometimes evolve out of spike and wave discharge. ${ }^{12.39}$ When this occurs, it is preceded by a breakdown of recurrent inhibition (Figure 5A). Thus it does appear that from time to time the GABA-ergic inhibitory mechanisms involved in spike and wave discharge are weakened and begin to fail, and when this occurs, the seizure pattern changes from that typical for absence attacks to a convulsive pattern: the spike and wave discharge in the EEG is then replaced by high voltage rhythmic sharp wave discharges typical for convulsive seizures. Such a seizure, in contrast to the absence-like seizure associated with spike and wave discharge, is followed by postictal depression. ${ }^{39}$

\section{Cellular Mechanisms of Convulsive and Partial Seizures}

From the observations summarized above, we can conclude that during the transition from spike and wave discharge to convulsive seizures the GABA-ergic inhibitory mechanism breaks down. Such a breakdown is known to occur in models of partial and convulsive seizures both in the interictal and ictal state. ${ }^{36}$. $37,40,41,42,43,44$

An example of this is the breakdown of GABA sensitivity and thus GABA-ergic mediated inhibition which occurs in response to tetanic stimulation of the hippocampus which commonly leads to a convulsive type of seizure discharge..$^{40,41}$ During such stimulation GABA sensitivity is initially preserved

Figure 3 - Oscillatory pattern in cortical and thalamic neurons during SW discharge in FGPE. There is increased excitation during the EEG spike and classical $\mathrm{Cl}^{-}$-sensitive postsynaptic inhibition during the wave component of the $S W$ complex. (A) Computer-generated EEG average and unit time histograms in cortex and thalamus. The activity of two single neurons, one in the thalamus, the other in the cortex was recorded; both were located in the same thalamocortical sector. Vertical height in the unit histograms is a measure of action potential firing probability of each neuron at the corresponding time in the EEG. Note increased firing probability during the spike, and markedly reduced firing probability during the slow wave component of the cortical and thalamic SW discharge. (B) and $(C) E E G$ (upper) and intracellular (lower) recordings with KCl-filled microelectrodes of SW activity in the pericruciate cortex induced by parenteral penicillin in the cat. Intracellularly, the oscillation consists of an alternation of brief depolarizing potentials (EPSPs) capped by action potentials (often in clusters) at the time of the spike component in the EEG and longer-lasting hyperpolarizations at the time of the slow wave component of the EEG during which no action potentials occur. (B) and $(C)$ are from two different cells. In $[C(a)] \mathrm{Cl}^{-}$has been iontophoretically injected into the neuron: it reverses the first part of the hyperpolarization and reduces the second. $[C(b)]$ Averages of the intracellular recordings from the same neuron before, during and after $C 1^{-}$injection into the cell; the early hyperpolarization is reversed by $\mathrm{Cl}^{-}$injection. Failure of this reversal to immediately disappear after discontinuation of $C \mathrm{I}^{-}$iontophoresis demonstrates that it is due to $\mathrm{CI}^{-}$loading of the cell and not merely to current injection. (A from Avoli M, Gloor P and Kostopoulos $G$. (1982) in Advances in Epileptology. XIII Epilepsy International Symposium (Akimoto H, Kasamatsuri H, Seino M, Ward A, eds. 493-496, Raven Press; B from Giaretta et al15). 


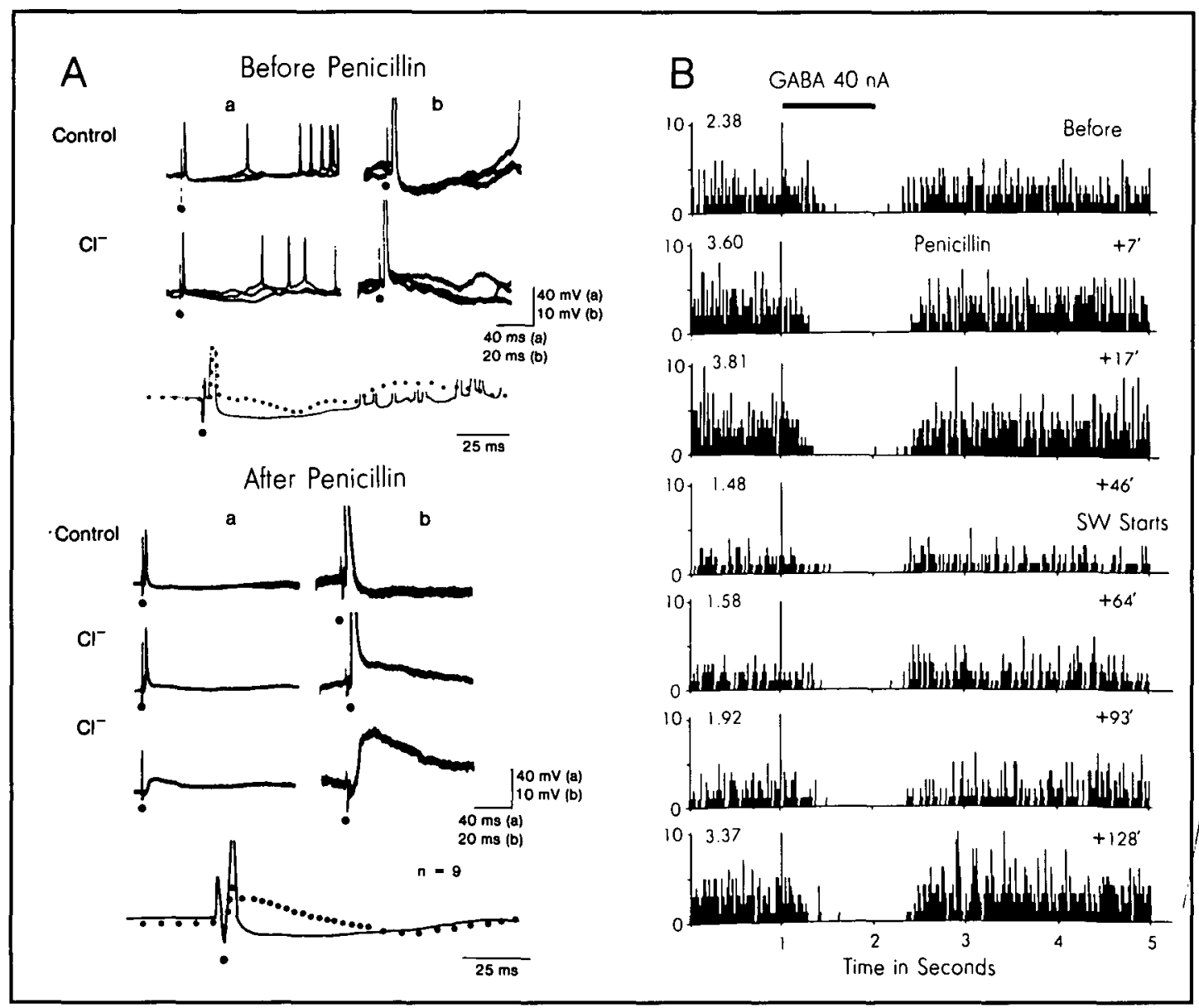

Figure 4 - Preservation of recurrent inhibition and of GABA sensitivity of cortical neurons during FGPE. (A) Recurrent inhibition elicited by antidromic pyramidal tract stimulation before and after intramuscular penicillin sufficient to induce SW discharge is unaltered. Intracellular recording from motor cortex neurons. Hyperpolarization remains $C 1^{-}$sensitive both before and after penicillin. (The cells recorded before and after penicillin were not the same.) Columns $a$ and $b$ recorded with different amplification. Records with solid and dotted lines are averaged responses before (solid line) and after (dotted line) intracellular $\mathrm{Cl}^{-}$injection: early part of hyperpolarization reversed both before and after penicillin. (B) Extracellularly recorded unit histogram of a cortical neuron during GABA iontophoresis before and after intramuscular penicillin. GABA pulses arrest unit firing equally well before and after penicillin, even after the development of SW discharge in the EEG. (A. From Giaretta et alls, B. from Kostopoulos 14 with permission).

for a brief period of time, but then collapses and remains suppressed for some time after the termination of tetanic stimulation (Figure 5B). This situation contrasts starkly with that prevailing during spike and wave discharge, where GABA sensitivity is fully preserved (Figure 4B).

Traub and Wong ${ }^{42,43}$ have modeled on a computer the consequences of the removal of inhibition from an interconnected neuronal network. Under such circumstances discharge of one neuron will lead to an avalanche of discharges involving all members of the interconnected network which then exhibit a nearly synchronous response. The computer generated discharge pattern displayed by modeled single cells within such a network is surprisingly similar to that recorded interictally from single cells in the hippocampus or cerebral cortex exposed to a convulsant agent such as penicillin and known as the paroxysmal depolarization shift or PDS (Figure 6). $34,45,46$ The consequence of removal of inhibition is that the EPSPs become prolonged. ${ }^{36}$ They are capped by a burst of action potentials of which the initial ones are full-sized and of short duration, while the late ones are small and of longer duration (Figure 6). The initial short-duration, large action potentials are mediated by $\mathrm{Na}^{+}$while the later smaller and longer-duration ones are mediated by $\mathrm{Ca}^{2+} .34,47$ Under these conditions, therefore, $\mathrm{Ca}^{2+}$ appears to be able to enter into the cell and becomes a carrier of the action potential. It is now evident that this sequence of events is due to the activation of $\mathrm{N}$-methyl-D-aspartate (NMDA) receptors by the excitatory transmitter, most likely glutamate or aspartate. ${ }^{48,49,50,51,52}$ Activation of this receptor is not only dependent upon the presence of the transmitter, but also upon depolarization of the postsynaptic membrane which dislodges magnesium ions that normally block the NMDA channel (Figure 8A). $50,52,53,54$ Normally the inhibition prevents the occurrence of this prolonged depolarization and thus does not allow NMDA receptors to become activated. Activation of the NMDA receptor activates a $\mathrm{Ca}^{2+}$ conductance and under these conditions $\mathrm{Ca}^{2+}$ can enter into the cell (Figure $8 \mathrm{~A}) .52,55,56,57,58$ Under normal conditions this mechanism is probably involved in neuronal plasticity, particularly in longterm potentiation which may provide a physiological substrate responsible for learning. $52,58,59,60$ However, with a marked 


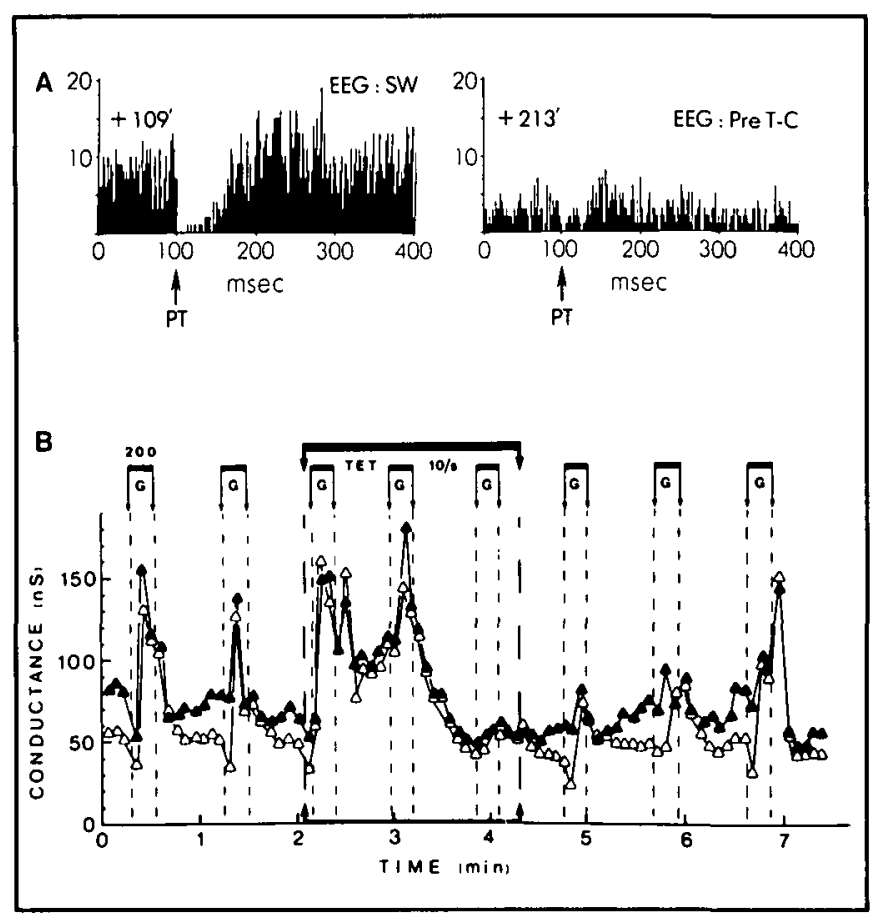

Figure 5-A. Breakdown of recurrent inhibition in FGPE with transition to generalized convulsive seizure. Post-stimulus time histograms of a single motor cortex neuron were computed. PT: time of antidromic stimulation of the pyramidal tract. On the left, while the EEG showed recurrent spike and wave discharges, this antidromic stimulation is followed by an inhibitory pause indicating activation of the intracortical recurrent inhibitory pathway. On the right (Pre $T-C)$ recurrent inhibition has almost totally broken down shortly before the onset of a generalized convulsive seizure (From Kostopoulos et al ${ }^{12}$ ).

$B$. Breakdown of GABA-sensitivity of hippocampal neurons with tetanic stimulation of the fimbria hippocampi. Short horizontal bars labeled $G$ : iontophoretic GABA pulses to a hippocampal neuron. Long horizontal bar labeled TET 10/s: duration of tetanic fimbrial stimulation. Open and solid triangles: measures of membrane conductance (resting and during postsynaptic inhibitory potential, respectively). Peaks of conductance increase indicate preserved GABA action. This is seen with each GABA pulse before and during early tetanic stimulation. Halfway through the latter the peaks disappear signalling loss of GABA sensitivity. This depression outlasts the end of stimulation. (From Ben-Ari and Krnjevic ${ }^{4 I}$ ).

breakdown of inhibition as it occurs in epilepsy, the NMDA channel opening is prolonged and an excess of $\mathrm{Ca}^{2+}$ is able to penetrate the cell. This must be the case, particularly during seizures during which the neuronal membrane of the discharging cell remains in a depolarized state for the duration of the attack (Figure 7). ${ }^{61,62} \mathrm{It}$ is to be assumed that under these conditions the magnesium block of the NMDA channel is completely relieved and $\mathrm{Ca}^{2+}$ can enter into the cell freely (Figure 8A). This explains why in convulsive seizures there is a considerable drop in extracellular $\mathrm{Ca}^{2+}$, the $\mathrm{Ca}^{2+}$ ions being transported from the extra-, into the intracellular space (Figure 8B). ${ }^{63,64,65,66,67}$ Since this massive influx of $\mathrm{Ca}^{2+}$ into the cell is dependent upon prolonged depolarization made possible by the blockage of inhibition, one would expect that it should not occur during spike and wave discharge where inhibition is preserved. Indeed, in the photosensitive baboon, it has been shown that when intermittent photic stimulation elicits multiple spike and wave discharge,

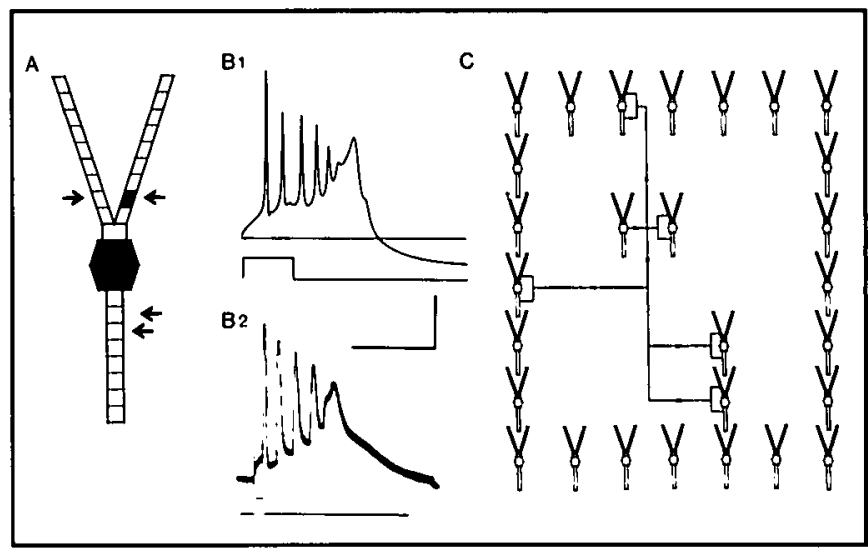

Figure 6-Neuronal network modeled by Traub and Wong. 42

A: Model of individual neuron $\left(\mathrm{Na}^{+}, \mathrm{K}^{+}, \mathrm{Ca}^{2+}\right.$ active ionic conductances shaded; arrows: sites of excitatory inputs). Bl: Burst response of a model neuron produced by an intracellular pulse; B2: similar burst recorded in a CA3 hippocampal neuron in response to a pulse. C shows the whole network in which there are no inhibitory synaptic inputs. Every cell sends out an output to an average of five other cells. In such a neuronal network without inhibition discharge of one neuron initiates a cascade of excitation producing nearly' synchronous bursting of each neuron receiving an input. The responses of these neurons are virmally identical with those shown in BI and B2. They resemble parorysmal depolarization shifts $(P D S)$ seen in experimental foci produced by topical application of convulsant drugs. Note the declining amplitude of action potentials with low amplitude long duration action potentials at the end of the burst which are thought to be mediated by $\mathrm{Ca}^{2+}$ entry. ${ }^{34.47}$ (From Traub and Wong, ${ }^{42}$ copyright 1982 by the AAAS.)

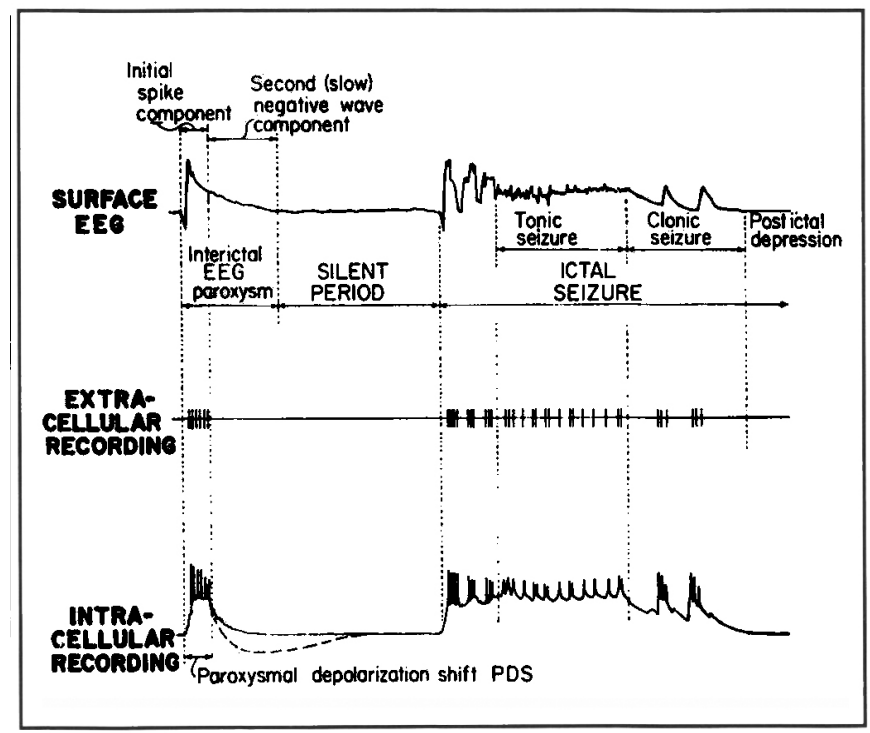

Figure 7 - Schematic diagram of relations between cortical dis. charges and both intracellular and extracellular activity in an epileptic focus. An isolated interictal discharge (EEG spike - PDS) and tonic-clonic ictal activity is shown. Note prolonged depolarization during seizure (From Ayala et al62 with permission).

only a small drop in extracellular $\mathrm{Ca}^{2+}$ occurs; soon, however, as a convulsive seizure develops, there is a very large drop in extracellular $\mathrm{Ca}^{2+}$, indicating massive influx of $\mathrm{Ca}^{2+}$ into the cells (Figure 8B). ${ }^{65}$ 
Unlike the entry of $\mathrm{Na}^{+}$during action-potential discharge, $\mathrm{Ca}^{2+}$ influx into the cell is not a short-lived phenomenon. Connor et al ${ }^{68}$ have shown that $\mathrm{Ca}^{2+}$ entry into a hippocampal neuron in response to a glutamate or NMDA pulse applied with a micropipette to its dendrite lingers on. There is first an early

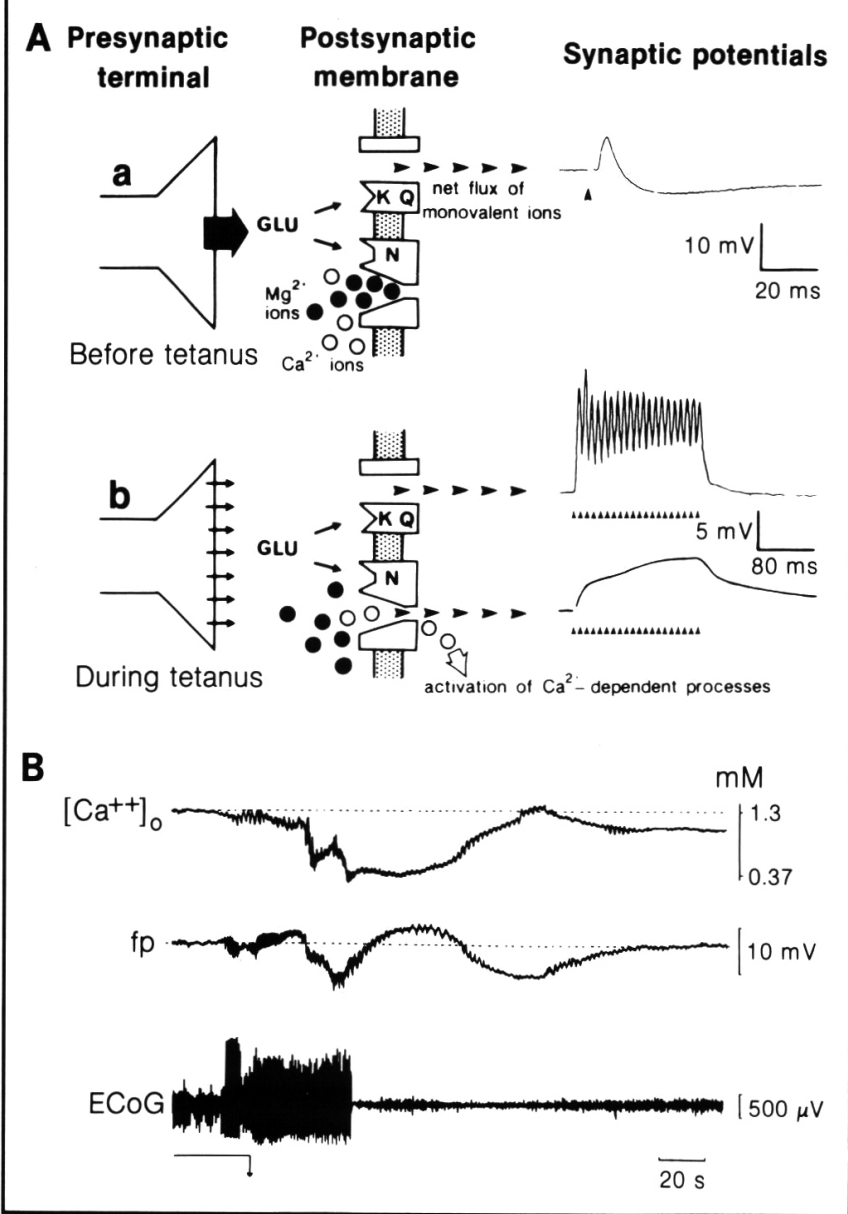

Figure 8A-A: Effects of (a) a single synaptic volley, and $(b)$ of highfrequency firing (as during a seizure) at a glutamatergic synapse. In (a) the released glutamate (GLU) acts on the kainate $(K)$ and quisqualate $(Q)$ receptors as well as on the NMDA $(N)$ receptors. The activated $K$ and $Q$ receptors open channels for monovalent $\left(\mathrm{Na}{ }^{+}\right.$ions which enter the cell (arrow heads) and induce an excitatory postsynaptic potential (EPSP) which is curtailed by a GABAmediated inhibitory postsynaptic potential (hyperpolarization following EPSP). The NMDA receptor-controlled channel $(N)$ is blocked by divalent $\mathrm{Mg}^{+}$ions (black circles). In (b) during high-frequency repetitive firing the postsynaptic membrane remains depolarized, in part because of failure of GABA-ergic inhibition. Membrane depolarization (right lower) releases the $\mathrm{Mg}^{2+}$ block at the $\mathrm{N}$ channel controlled by the NMDA receptor. $\mathrm{Ca}^{2+}$ ions (open circles) can now enter the cell where they may activate $\mathrm{Ca}^{2+}$-dependent processes. (From Collingridge and Bliss ${ }^{58}$ ).

$B$ : Changes in extracellular $\mathrm{Ca}^{2+}$ concentration during photosensitive epileptic seizures in the baboon (Papio papio). $\left[\mathrm{Ca}^{2+}\right]_{0 .}$ extracellular $\mathrm{Ca}^{2+}$ concentration (millimole scale $\mathrm{mM}$ on right); fp: field potential; ECoG: electrocorticogram. When spike and wave discharges appear (initial burst of high-voltage signals in ECoG) there is only a modest decrease in $\left[\mathrm{Ca}^{2+}\right]_{0}$. when the generalized convulsive seizure occurs (second more prolonged sequence of high-voltage signals in ECoG) there is a large drop in $\left.\mathrm{CCa}^{+}\right]_{0}$ (From Pumain et al65). local increase in $\mathrm{Ca}^{2+}$ permeability at the site of glutamate application but, after some delay, there is a renewed increase and the $\mathrm{Ca}^{2+}$ concentration continues to rise, such that three minutes later a sustained intracellular $\mathrm{Ca}^{2+}$ gradient has developed with the largest concentration in the region of the initial glutamate action (Figure 9). With repeated pulses at intervals of the order of minutes, the secondary rise in intracellular $\mathrm{Ca}^{2+}$ becomes accentuated and because of the long duration of the response there is a staircase effect leading to a long-lasting and considerable accumulation of $\mathrm{Ca}^{2+}$ within the cell. This longlasting rise in intracellular $\mathrm{Ca}^{2+}$ concentration can be prevented by sphingosine, a protein kinase $\mathrm{C}$ inhibitor, suggesting that the long-lasting $\mathrm{Ca}^{2+}$ response involves the activation of second messenger systems.
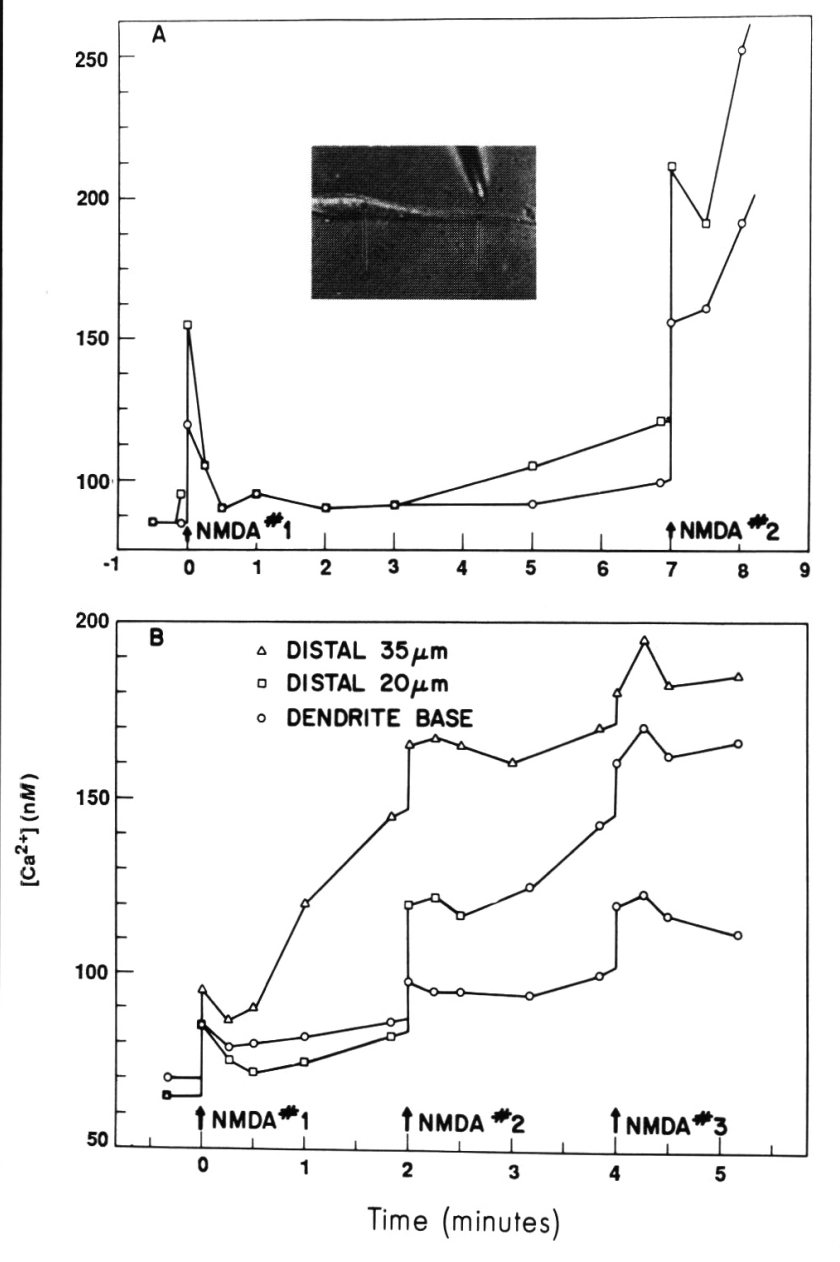

Figure 9-Changes in intracellular $\mathrm{Ca}^{2}+$ concentration $\left(/ \mathrm{Ca}^{2}+J_{i}(\mathrm{nM})\right.$ in dissociated hippocampal neurons measured by the $\mathrm{Ca}^{2+}+$ sensitive dye fura-2 resulting from an iontophoretic pulse of NMDA applied with a micropipette to the apical dendrite (as shown in inset). The ordinate measures the intracellular $\mathrm{Ca}^{2}+$ gradient between the den. drite where NMDA was applied and the soma. (A) The first stimulus, applied as a 2-second, 200-nA pulse, produced a short-lived gradient. The second stimulus, applied as three 1-second pulses in rapid succession, produced a large, long-lasting response. $(B)$ $\left[C a^{2}+\right]_{i}$ in a second neuron given three identical stimuli (I second. $200 \mathrm{nA})$. A sustained $\mathrm{Ca}^{2+}$ gradient developed after partial recov. ery from the first stimulus. (From Connor et al, ${ }^{68}$ copyright 1988 by the AAAS.) 


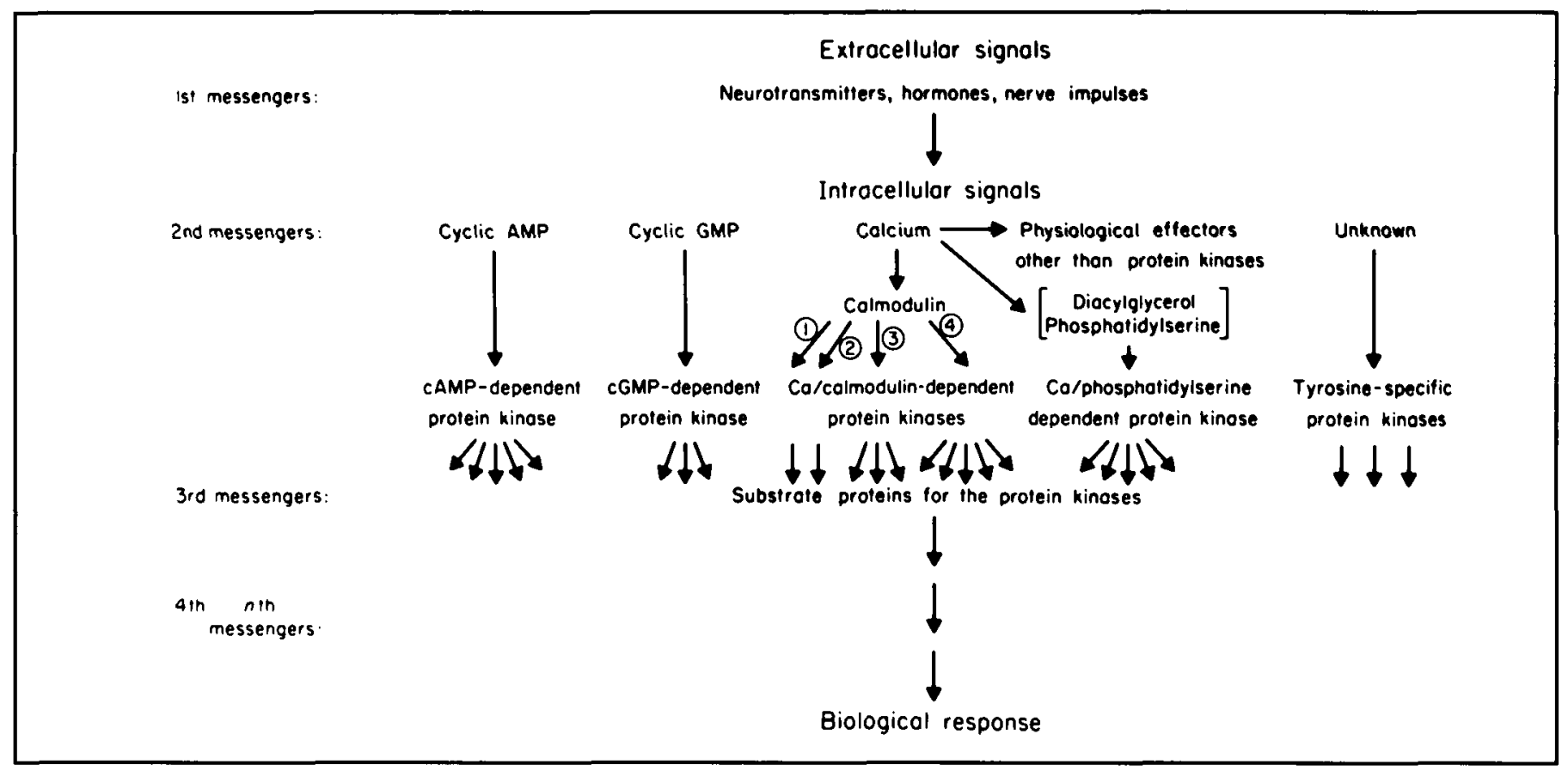

Figure 10 - The second messenger cascade after Greengard. (From Greengard 69 with permission).

For the neuron what are the consequences of this massive and prolonged entry of $\mathrm{Ca}^{2+}$ into the cell? It must be expected that in the course of seizures such $\mathrm{Ca}^{2+}$ accumulation must become considerable. Undoubtedly, under normal conditions when the amount of $\mathrm{Ca}^{2+}$ entering the cell through the activation of the NMDA channel is moderate, this change will contribute to the normal functioning of the neuron. It is known that $\mathrm{Ca}^{2+}$ entry into the cell turns on a whole cascade of second, third and $n$th messenger systems within the neuron ${ }^{69}$ (Figure 10) which leads to a number of long-lasting functional consequences. With moderate $\mathrm{Ca}^{2+}$ entry, as is to be expected under physiological conditions, one of these consequences appears to be plastic changes in the neuron. Of particular interest are those involved in long-term potentiation which may underlie the mechanism of learning. $52,58,70,71,72,73$ More massive or prolonged intraneuronal $\mathrm{Ca}^{2+}$ influx as it appears to occur during partial and convulsive epileptic seizures may, however, have deleterious consequences. Two such consequences need to be distinguished, the first is actual cell damage, either reversible or irreversible, and the other consists of structurally non-damaging plastic changes which may or may not be deleterious.

Let us first deal with the simpler problem of potential cell damage by $\mathrm{Ca}^{2+}$. When excess amounts of $\mathrm{Ca}^{2+}$ enter a cell, lipases and proteases may become activated. Some proteins, but particularly cytoplasmic organelles, the mitochondria and to a lesser extent the endoplasmic reticulum will mop up the excess $\mathrm{Ca}^{2+}$ which then becomes sequestered within these organelles. Prolonged depolarization of the cell to which $\mathrm{Ca}^{2+}$ entry contributes, leads to $\mathrm{Cl}^{-}$influx and osmotic cell damage, possibly even cell death. ${ }^{74,75,76}$ It has been shown by Griffiths et al ${ }^{74}$ that after prolonged seizure activity $\mathrm{Ca}^{2+}$ accumulates within mitochondria. This can be demonstrated by electronmicroscopy (Figure 11). If the epileptic discharge lasts for a considerable length of time or occurs at short intervals as in status epilepticus, mitochondria may be damaged either reversibly, or in some instances irreversibly. In the latter instance this can lead to cell death. This, together with osmotic cell damage, is the most likely cause for the cellular damage, particularly in the hippocampus, that can occur after prolonged seizures. It may explain the famous "hippocampal sclerosis" of Spielmeyer"17 which is often the consequence of status epilepticus or of prolonged febrile seizures in children. 18,19,21 These changes need not be confined to children. Mouritzen Dam ${ }^{20}$ has provided evidence suggesting that hippocampal neuronal loss in epileptics increases throughout life as a function of the duration of the seizure disorder. That it is actually the high discharge rate of neurons occurring during seizures which is responsible for this damage, is suggested by the experiments of Sloviter ${ }^{77}$ who demonstrated that repetitive electrical stimulation of the perforant path to the hippocampus leads to cellular damage in that structure if a high rate of discharge of dentate granule cells, unopposed by inhibition, takes place. Such damage occurs in the absence of any metabolic disturbance or of any drugs that might have been used to induce neuronal hyperactivity (Figure 12).

Let us now turn to structurally non-damaging plastic changes produced by $\mathrm{Ca}^{2+}$ entry. These result from the activation of multiple intracellular second and higher order messenger systems. They include besides $\mathrm{Ca}^{2+}$, cyclic AMP, cyclic GMP, several protein kinases, the phosphoinositol cascade including diacylglycerol and inositol triphosphate (Figure 10). There are interactions between these multiple systems in which often $\mathrm{Ca}^{2+}$ is involved. $60,69,70,71,72,73$ The principal and most important effect of activating these second messenger systems is that the short-lived electrophysiological processes taking place at the neuronal membrane are converted into intracellular processes of much longer duration which in their turn may secondarily have 
repercussions on the neuronal membrane and alter its excitability. These intracellular long-duration processes cover a wide range of time courses from a few minutes, to days, weeks or even possibly to the remaining lifetime of the organism. It is thus thought possible that these processes under normal conditions are the substrate for both short- and long-term memory. ${ }^{70}$ Since they are most powerfully activated by repetitive neuronal firing and may even only occur under such conditions, it is obvious that they will become involved in the course of every epileptic seizure discharge where NMDA receptor activation and thus significant $\mathrm{Ca}^{2+}$ influx into the nerve cell occurs. In the course of seizures these physiological processes become exaggerated and exceed the limits of normality. This is probably the case in most seizures with the likely, but notable exception of absence attacks. It is therefore to be expected that seizures associated with $\mathrm{Ca}^{2+}$ entry into the neuron will leave long-lasting or sometimes even enduring footprints in the brain.

Not all of these Iong-lasting second messenger-induced changes need to be permanent, however. To some extent this depends upon what second messenger system becomes predom-

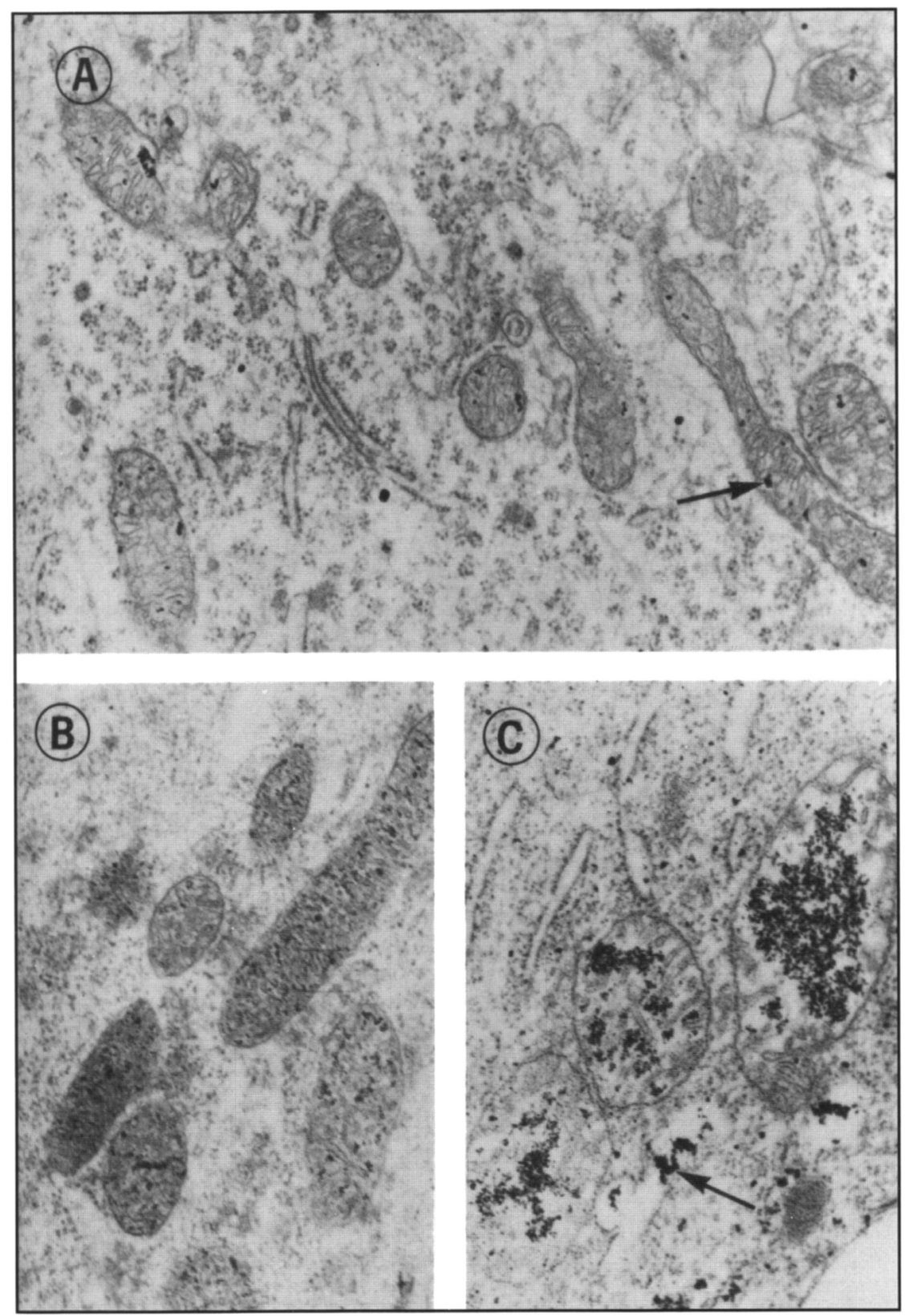

Figure $11-$ Mitochondrial $\mathrm{Ca}^{2+}$ accumulation in prolonged seizures. The Ca ${ }^{2+}$ has been stained by the oxalate-pyroantimonate technique which forms electron-dense deposits (black dots). (A) Mitochondria of control pyramidal neuron demonstrating a few small discrete electron-dense deposits (arrow). 140,000 . (B) Following $2 \mathrm{~h}$ of bicuculline-induced seizures, these pyramidal neuron mitochondria look structurally unaltered but contain many more calcium pyroantimonate deposits than the control (cf. Fig. 3A). $x 40,000$. (C) Another neuron from the same animal as in (B), demonstrating swollen and disrupted mitochondria with very dense deposits. A few are also seen in the widened endoplasmic reticulum (arrow). $x 40,000$. (From Griffiths et al74 with permission). 
inantly involved and to what degree. Second messenger systems involving only cytosolic components may produce both shortand long-lasting changes. These may influence the secretion of and the sensitivity to neurotransmitters, the permeability of ionic channels, the induction of enzymes such as tyrosine hydroxylase, increase of glutamate binding capacity of synaptic membranes and facilitation of transmitter release. ${ }^{71,73,78,79}$

Longer-lasting processes involving cytosolic second messenger systems include the phosphorylation of protein pp $46 / \mathrm{F}_{1}$ which is known to be involved in the chemotactically guided

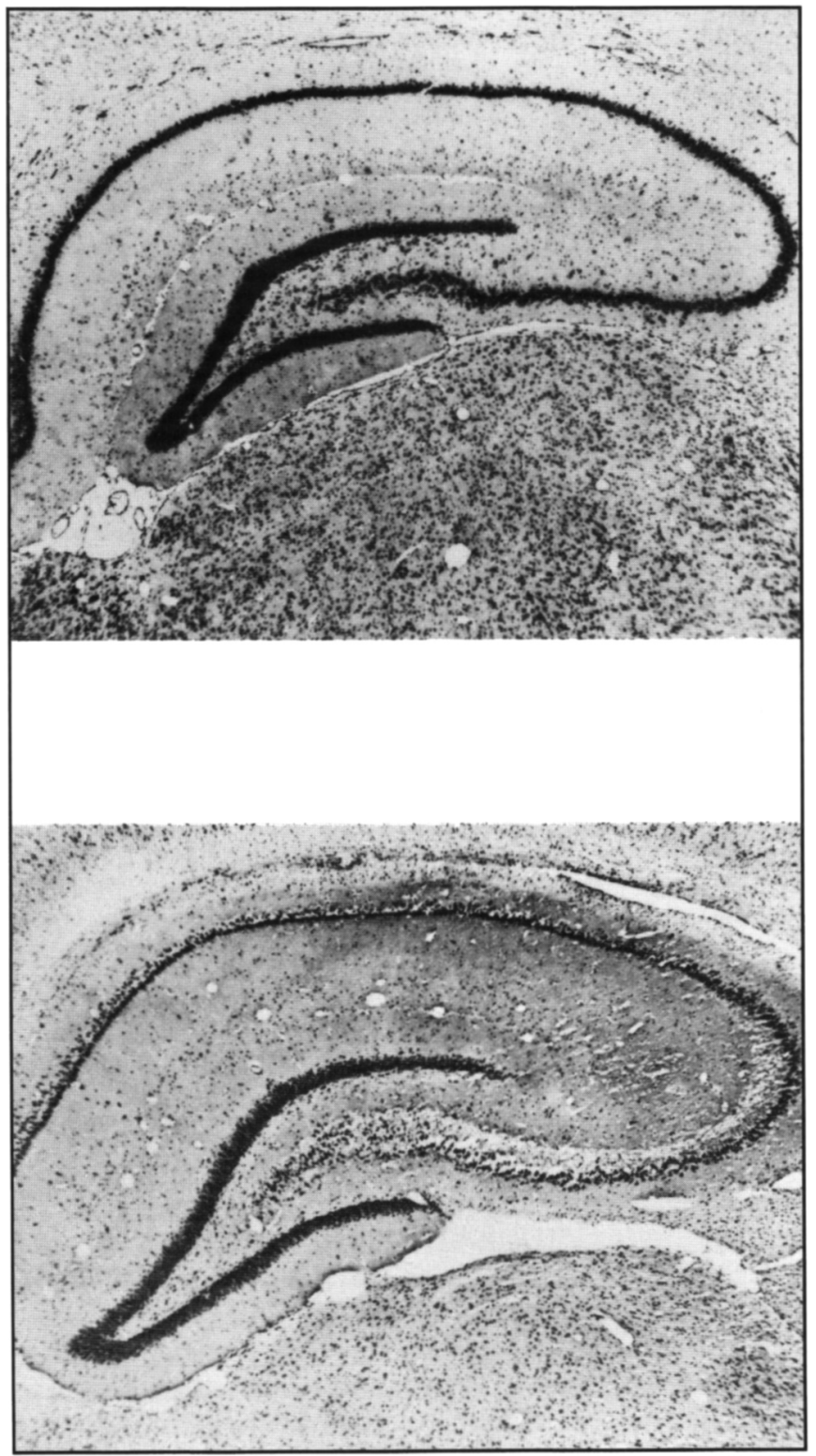

Figure 12 - Hippocampal damage resulting from prolonged repetitive stimulation-induced excitation of the dentate gyrus. Upper: intact hippocampus of a rat in which the perforant path had been subjected to 24 hrs of continuous repetitive stimulation insufficient to block inhibition in the dentate gyrus; dentate granule cell output was thus submaximal. Lower: Damage to sectors $C A_{3}$ and $C A_{1}$, of hippocampus after 24 hrs of repetitive perforant path stimulation in which recurrent inhibition in the dentate gyrus was lost and dentate output to hippocampus was unchecked. (From Sloviter 77 ). elongation of pseudopodia in leucocytes and of the growth cones of developing neurons. ${ }^{72}$ This protein, however, also exists in the adult hippocampus and is phosphorylated in the course of long-term potentiation induced by repetitive afferent stimulation of the hippocampus. ${ }^{80}$ It may thus be involved in synaptic growth processes at potentiated synapses 72 and provide a structural basis for memory formation, and, in epilepsy, for kindling. It may thus be a factor in entrenching the seizure tendency more firmly in the brain. Because of the relative sequestration of the cytosolic compartment of the dendritic spine, $\mathrm{Ca}^{2+}$ accumulation in that subcompartment of the cell occurring during high-frequency repetitive activation of spine synapses, could locally become quite high. Because this process would be confined to the involved spine, the plastic changes induced by the strong synaptic activation of that synapse could be restricted to that spine exclusive of other sites. ${ }^{60}$ One may speculate that in some forms of epilepsy changes of this kind may explain why in some cases very specific stimuli are required to precipitate an attack.

Second messenger systems are, however, not necessarily confined to the cytosolic compartment of the cell. The cascade extends to the nucleus of the cell and involves the genome. Particularly the c-fos and to a lesser extent the c-myc protooncogenes are targets of these second messenger actions on the genome. ${ }^{70,79,82,83,84}$ The products of these genes are nuclear proteins that are involved in transcription and mRNA processing. The cascade leading to the expression of the c-fos protooncogene is set in motion by $\mathrm{Ca}^{2+}$ entry into the cell; it involves calmodulin and kinases, and probably a transcription activating protein entering the nucleus ${ }^{84}$ where it induces expression of the c-fos proto-oncogene through the activation of a transcriptase inducing the synthesis of the appropriate messenger RNA. The resulting gene product, the c-fos protein, is a nuclear protein that regulates the expression of the genes that are particularly involved in cell growth and differentiation and may thus be suspected of playing a role in long-term synaptic adaptation. It is to be expected that genomic mechanisms of this kind should become activated as a consequence of the massive intraneuronal $\mathrm{Ca}^{2+}$ entry that takes place in the course of seizures. Morgan et $\mathrm{al}^{81}$ and Dragunow and Robertson ${ }^{85,86}$ have shown that seizure activity or electrical stimulation as used in kindling leads to the expression of the c-fos proto-oncogene, particularly in the hippocampus and piriform cortex, but also in other areas of the brain particularly the cerebral cortex. A single pentylenetetrazol-induced seizure will produce this change which is however a slowly developing and long-lasting effect. The gene product of the c-fos gene, the c-fos protein, can be histochemically demonstrated in these structures as a constituent of the cell nucleus (Figure 13). These experiments show that increased $\mathrm{Ca}^{2+}$ entry into the cell exerts an action on the genome by acting on the nuclear DNA. This effect is a consequence of the seizure and is not involved in its mechanism. The gene expression becomes evident only after the seizure is over and gradually intensifies over 4 hours (Figure 13). It returns to baseline after 16 hours during which period repeated seizures can be elicited by reinjections of pentylenetetrazol, but the c-fos response is refractory during this period.

What the consequences of the activation of this gene through $\mathrm{Ca}^{2+}$ entry as a consequence of seizures could be, remains to be determined, but since c-fos is involved in cell differentiation one 
is tempted to suspect that such phenomena as kindling and possibly the formation of mirror foci could be due to some restructuring of synapses involved in the seizure. Receptor synthesis or sensitization may be one of these changes and may for instance explain why NMDA receptors are involved in the synaptic transmission in the dentate gyrus after, but not before kindling. ${ }^{87}$

\section{Conclusions}

It appears likely that under conditions under which $\mathrm{Ca}^{2+}$ can enter in large amounts into cells in the course of seizures, short or long-lasting or even permanent changes can occur which may be an important pathogenetic factor in chronic epileptogenic disorders of the partial or convulsive type. These changes may be cell dysfunction or damage, either transient as in the postictal state, or permanent. Transient changes may include temporary impairment of cellular oxidative metabolism due to mitochondrial dysfunction which may contribute to postictal depression of neuronal function; or they may be responsible for the increase in tyrosine hydroxylase activity ${ }^{88}$ which may possi- bly play a role in postictal psychosis. Long-lasting aftereffects may involve plastic neuronal changes which alter the responsiveness and excitability of the neuronal networks involved in seizures and, through a mechanism related to kindling, may entrench an epileptogenic condition more solidly in the brain and thus render it increasingly more resistant to therapy as seizures keep recurring. None of these changes are likely to occur in the course of absence seizures, because the preservation of GABA-ergic inhibition prevents the activation of NMDA receptors and hence forestalls massive entry of $\mathrm{Ca}^{2+}$ into the cell. It is for these reasons most likely that absence epilepsy is benign. The lack of postictal, clinical or EEG signs of neuronal dysfunction could be explained by the fact that no significant $\mathrm{Ca}^{2+}$ entry into the cell occurs. The lack of any form of permanent brain damage induced by recurrent absence attacks could be accounted for on the same basis. Furthermore, it is likely that kindling does not occur during pure absence epilepsy and this may explain the relatively high rate of spontanteous remission and the usually fairly good response to anticonvulsant therapy. Finally, it is conceivable that the somewhat

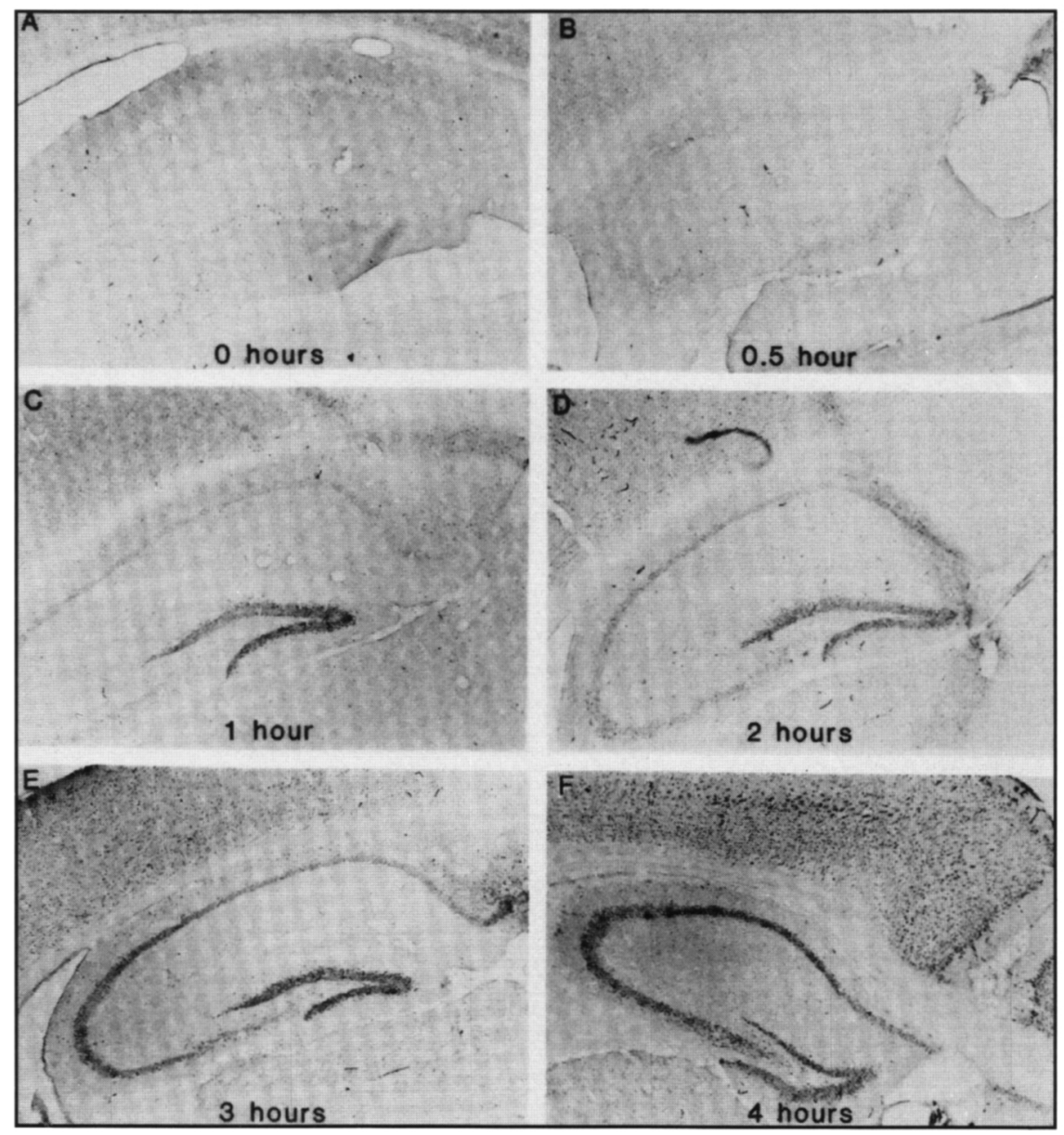

Figure 13 - Immunofluorescent demonstration of c-fos protein synthesis in mouse hippocampus by a single pentylene-tetrazole-induced seizure (50 $\mathrm{mg} / \mathrm{kg}$ intraperitoneal). Dark spots indicate immunofluorescent cell nuclei which are present not only in hippocampus but in nearby isocortical areas. A to $F$ shows the time course of the response. The data are representative coronal sections at approximately the same position in the brain to show the complete hippocampal formation. Immunostaining of c-fos protein first appears in the dentate gyrus at 30 minutes after seizure and is maximal between I and 2 hours. The hippocampus proper becomes stained with a slower onset and is maximal between 3 and 4 hours. During this time course, the cerebral isocortical layers become fos-positive at different times. In addition, after 4 hours the caudate becomes positive (x50). (From Morgan et al, 81 copyright 1987 by the AAAS). 
poorer prognosis for remission encountered in patients with absence seizures who in addition have convulsive attacks, may find its explanation on the basis of the mechanism reviewed in this paper.

The issues discussed so far are not only of theoretical interest. Some practical consequences derive from them. One must be mindful that seizures may by themselves represent a pathogenetic factor in epilepsy. Since many of the second messengerinduced changes are of long duration, repeated seizures at short intervals must be particularly deleterious, because there is a cumulative effect of $\mathrm{Ca}^{2+}$ entry into the nerve cell under these conditions which may overwhelm its capacity to deal with it effectively. It must be realized that the risks presented by repeated seizures occurring at short intervals are not confined to generalized convulsive attacks. Because NMDA receptors are most concentrated in limbic structures, these are most vulnerable to the damaging effects of repeated seizures occurring at short intervals, even if clinically they may appear to be relatively minor. Vigorous anticonvulsant treatment is thus indicated not only in major convulsive status epilepticus, but also in conditions when apparently minor clinical seizures occur repeatedly at short intervals. Because the damage to the brain in status epilepticus is mostly due to the local consequences of the seizure discharge in the brain and much less so to secondary repercussions from the involvement of the skeletal muscles and the cardio-respiratory system, treatment of status epilepticus must aim not only at maintaining cardiorespiratory function at optimal levels and at preventing convulsive movements, but must also attempt to stop the seizure discharge, even if under ICU emergency treatment conditions it may no longer be capable of expressing itself outwardly by convulsive movements. EEG recordings in the ICU under these conditions may help to demonstrate that the therapeutic measures instituted have not only suppressed the outward motor manifestations of seizure activity, but have brought it under control in the brain itself.

\section{ACKNOWLEDGEMENTS}

The experimental work on feline generalized penicillin epilepsy summarized in this paper was supported by Grant MT-3140 of the Medical Research Council of Canada.

\section{REFERENCES}

1. Gastaut H. "Benign" or "functional" (versus "organic") epilepsies in different stages of life: an analysis of the corresponding agerelated variations in the predisposition to epilepsy. In: Broughton RF, ed. Henri Gastaut and the Marseilles School's Contribution to the Neurosciences. Electroenceph Clin Neurophysiol 1982; Suppl 35: 17-44.

2. Lennox WG, Lennox MA. Epilepsy and related disorders. Boston, Little, Brown 1960; Vol 1.

3. Dalby MA. Epilepsy and 3 per second spike and wave rhythms. A clinical, electroencephalographic and prognostic analysis of 346 patients. Acta Neurol Scand 1969; 45, Suppl 40: 183.

4. Gastaut H, Zifkin BG. Classification of the epilepsies. J Clin Neurophysiol 1985; 2: 313-326.

5. Loiseau P. Childhood absence epilepsy. In: Roger J, Dravet C, Bureau M, Dreifuss FE, Wolf P, eds. Epileptic Syndromes in Infancy, Childhood and Adolescence. London, John Libby 1985; 106-120.

6. Berkovic SF, Andermann F, Andermann E, Gloor P. Concepts of absence epilepsies: discrete syndromes or biological continuum? Neurology 1987; 37: 993-1000.
7. Janz D. Neurological morbidity of severe epilepsy. Epilepsia 1988; 29, Suppl 1: S1-S8.

8. Wolf $\mathrm{P}$, Inoue $\mathrm{Y}$. Therapeutic response of absence seizures in patients of an epilepsy clinic for adolescents and adults. J Neurology 1984; 231: 225-229.

9. Gastaut H, Zifkin BG, Mariani E, Puig JS. The long-term course of primary generalized epilepsy with persisting absences. Neurology 1986; 36: 1021-1028.

10. Gloor P. Generalized epilepsy with spike-and-wave discharge: a reinterpretation of its electrographic and clinical manifestations. Epilepsia 1979; 20: 571-588.

11. Gloor P. Electrophysiology of generalized epilepsy. $I n$ : Schwartzkroin PA, Wheal H, eds. Electrophysiology of Epilepsy. London, Academic Press 1984: 107-136.

12. Kostopoulos G, Avoli M, Gloor P. Participation of cortical recurrent inhibition in the genesis of spike and wave discharges in feline generalized penicillin epilepsy. Brain Res 1983; 267: 101-112.

13. Giaretta D, Kostopoulos G, Gloor P, Avoli M. Intracortical inhibitory mechanisms are preserved in feline generalized penicillin epilepsy. Neuroscience Lett 1985; 99: 203-208.

14. Kostopoulos G. Neuronal sensitivity to GABA and glutamate in generalized epilepsy with spike and wave discharges. Exp Neurol 1986; 92: 20-36.

15. Giaretta D, Avoli M, Gloor P. Intracellular recordings in pericruciate neurons during spike and wave discharges of feline generalized penicillin epilepsy. Brain Res 1987; 405: 68-79.

16. Gloor P, Fariello RG. Generalized epilepsy: some of its cellular mechanisms differ from those of focal epilepsy. Trends in Neurosci 1988; 11: 63-68.

17. Spielmeyer W. Die Pathogenese des epileptischen Krampfes. Z ges Neurol Psychiat 1927; 109: 501-520.

18. Margerison JH, Corsellis JAN. Epilepsy and the temporal lobes. Brain 1966; 89 II: 499-530.

19. Ounsted C, Lindsay J, Norman R. Biological factors in temporal lobe epilepsy. In: Clinics in Developmental Medicine No. 22. London: The Lavenham Press Ltd 1966; 135.

20. Mouritzen Dam A. Hippocampal neuron loss in epilepsy and after experimental seizures. Acta Neurol Scand 1982; 66: 601-642.

21. Sagar HJ, Oxbury JM. Hippocampal neuron loss in temporal lobe epilepsy: correlation with early childhood convulsions. Ann Neurol 1987; 22: 334-340.

22. Gowers WR. Epilepsy and other chronic convulsive states. London: Churchill 1881.

23. Reynolds EH, Elwes RDC, Shorvon SD. Why does epilepsy become intractable? Lancet 1983; 2: 952-954.

24. Reynolds EH. The prevention of chronic epilepsy. Epilepsia 1988; 29, Suppl 1: 525-528.

25. Taylor-Courval D, Gloor P. Behavioral alterations associated with generalized spike and wave discharges in the EEG of the cat. Exp Neurol 1984; 83: 167-186.

26. Guberman A, Gloor P, Sherwin AL. Response of generalized penicillin epilepsy in the cat to ethosuximide and diphenylhydantoin. Neurol 1975; 25: 758-764.

27. Pellegrini A, Gloor P, Sherwin AL. Effect of valproate sodium on generalized penicillin epilepsy in the cat. Epilepsia 1978; 19: 351-360.

28. Kostopoulos G, Gloor P, Pellegrini A, Siatitsas I. A study of the transition from spindles to spike and wave discharge in feline generalized penicillin epilepsy: EEG features. Exp Neurol 1981; 73: 43-54.

29. Kostopoulos G, Gloor P, Pellegrini A, Gotman J. A study of the transition from spindles to spike and wave discharge in feline generalized penicillin epilepsy: microphysiological features. Exp Neurol 1981; 73: 55-77.

30. McLachlan RS, Avoli M, Gloor P. Transition from spindles to generalized spike and wave discharge in the cat: simultaneous single-cell recordings in cortex and thalamus. Exp Neurol 1984; 85: 413-425.

31. Avoli M, Gloor P, Kostopoulos G, Gotman J. An analysis of penicillin-induced generalized spike and wave discharges using 
simultaneous recordings of cortical and thalamic single neurons. J Neurophysiol 1983; 50: 819-837.

32. Curtis DR, Game CJA, Johnston GAR, McCullock RM, MacLachlan RM. Convulsive action of penicillin. Brain Res 1972; 43: 242-245.

33. Davidoff RA. Penicillin and inhibition in the cat spinal cord. Brain Res 1972; 45: 638-642.

34. Prince DA. Neurophysiology of epilepsy. Annu Rev Neurosci 1978; 1: 395-415.

35. Dingledine R, Gjerstad L. Reduced inhibition during epileptiform activity in the in vitro hippocampal slice. J Physiol (London) 1980; 305: 297-313

36. Schwartzkroin PA, Prince DA. Changes in excitatory and inhibitory synaptic potentials leading to epileptogenic activity. Brain Res 1980; 183: 61-76.

37. Krnjevic K. GABA-mediated inhibitory mechanisms in relation to epileptic discharges. In: Jasper $\mathrm{H}$, van Gelder N, eds. Basic Mechanisms of Neuronal Hyperexcitability. New York: Alan R. Liss, Inc. 1983; 249-280.

38. Quesney LF, Gloor P. Generalized penicillin epilepsy in the cat: correlation between electrophysiological data and distribution of ${ }^{14} \mathrm{C}$-penicillin in the brain. Epilepsia 1978; 19: 35-45.

39. Avoli M, Siatitsas I, Kostopoulos G, Gloor P. Effects of post-ictal depression on experimental spike and wave discharges. Electroenceph Clin Neurophysiol 1981; 52: 372-374.3.

40. Ben-Ari Y, Krnjevic K, Reinhardt W. Hippocampal seizures and failure of inhibition. Can J Physiol Pharmacol 1979; 57: 14621466.

41. Ben-Ari Y, Kmjevic K. Actions of GABA on hippocampal neurons with special reference to the aetiology of epilepsy. In: Morselli PL, Löscher W, Lloyd RG, Meldrum MB, Reynolds EH, eds. Neurotransmitters, Seizures, and Epilepsy. New York: Raven Press 1981; 63-73.

42. Traub RD, Wong RKS. Cellular mechanism of neuronal synchronization in epilepsy. Science 1982; 216: 745-747.

43. Traub RD, Wong RKS. Synchronized burst discharge in disinhibited hippocampal slice. II. Model of cellular mechanism. J Neurophysiol 1983; 49: 459-471.

44. Avoli M. Is epilepsy a disorder of inhibition or excitation? In: Epilepsy: Nistico G, DiPerri R, Meinhardt H, eds. An Update on Research and Therapy (Progress in Clinical and Biological Research). New York: Alan R Liss, Inc. 1983; 124: 23-37.

45. Matsumoto H, Ajmone Marsan C. Cortical cellular phenomena in experimental epilepsy: interictal manifestations. Exp Neurol 1964; 9: 286-304

46. Dichter M, Spencer WA. Penicillin-induced interictal discharges from the cat hippocampus. I. Characteristics and topographical features. J Neurophysiol 1969; 32: 649-662.

47. Wong RKS, Prince DA. Participation of calcium spikes during intrinsic burst firing in hippocampal neurons. Brain Res 1978; 159: $385-390$.

48. Coutinho-Netto J, Abdul-Ghani AS, Collins JF, Bradford HF. Is glutamate a trigger factor in epileptic hyperactivity? Epilepsia 1981; 22: 289-296.

49. Herron CE, Williamson R, Collingridge GL. A selective N-methyl$D$-aspartate antagonist depresses epileptiform activity in rat hippocampal slices. Neurosci Lett 1985; 61: $255-260$.

50. Dingledine R. NMDA receptors. What do they do? Trends in Neurosci 1986; 9: 47-49.

51. Avoli M, Olivier A. Bursting in human epileptogenic neocortex is depressed by an $\mathrm{N}$-methyl-D-aspartate antagonist. Neurosci Lett 1987; 76: 249-254.

52. Cotman CW, Monaghan DT, Ganong AH. Excitatory amino acid neurotransmission: NMDA receptors and Hebb-type synaptic plasticity. Annu Rev Neurosci 1988; 11: 61-80.

53. Mayer ML, Westhook GL, Guthrie PH. Voltage-dependent block by $\mathrm{Mg}^{2+}$ of NMDA responses in spinal cord neurones. Nature 1984; 309: 262-263.

54. Nowak L, Bregestovski P, Ascher P, Herbert A, Prochiantz A Magnesium gates glutamate-activated channels in mouse central neurones. Nature 1984; 307: 462-465.

55. MacDermott AB, Mayer ML, Westbrook GL, Smith SJ, Barker JL. NMDA-receptor activation increases cytoplasmic calcium con- centration in cultured spinal neurones. Nature 1986; 321 : 519 . 522.

56. Jahr CE, Stevens CF. Glutamate activates multiple single channel conductances in hippocampal neurones. Nature 1987; 325: 522525.

57. Mayer ML, MacDermott AB, Westbrook GL, Smith SJ, Barker JL. Agonist and voltage-gated calcium entry in cultured mouse spinal cord neurons under voltage clamp. J Neurosci 1987; 7: 3230-3244.

58. Collingridge GL, Bliss TVP. NMDA receptors - their role in longterm potentiation. Trends in Neurosci 1987; 10: 288-293.

59. Cotman CW, Iversen LL. Excitatory amino acids in the brain focus on NMDA receptors. Trends in Neurosci 1987; 10: 263265.

60. Nicoll RA, Kauer JA, Malenka RC. The current excitement in long term potentiation. Neuron 1988; 1: 97-103.

61. Matsumoto H, Ajmone Marsan C. Cortical cellular phenomena in experimental epilepsy: ictal manifestations. Exp Neurol 1964b; 9: $305-326$

62. Ayala GF, Matsumoto H, Gumnit RJ. Excitability changes and inhibitory mechanisms in neocortical neurons during seizures. J Neurophysiol 1970;33: 73-85.

63. Heinemann U, Lux HD, Gutnick MJ. Extracellular free calcium and potassium during paroxysmal activity in the cerebral cortex of the cat. Exp Brain Research 1977; 27: 237-243.

64. Louvel J, Heinemann U. Changes in $\left[\mathrm{Ca}^{2+}\right]_{0},\left[\mathrm{~K}^{+}\right]_{0}$ and neuronal activity during oenanthotoxin-induced epilepsy in cat sensorimotor cortex. Electroenceph Clin Neurophysiol 1983; 56: 457 466.

65. Pumain R, Ménini C, Heinemann U, Louvel J, Siva-Barrat C. Chemical synaptic transmission is not necessary for epileptic seizures to persist in the baboon Papio papio. Exp Neurol 1985; 89: 250-258.

66. Heinemann U, Hamon B. Calcium and epileptogenesis. Exp Brain Res 1986; 65: 1-10.

67. Avoli M, Louvel J, Pumain R, Olivier A. Seizure-like discharges induced by lowering $\left[\mathrm{Mg}^{2+}\right]_{0}$ in the human epileptogenic neocortex maintained in vitro. Brain Research 1987; 417: 199-203.

68. Connor JA, Wadman WJ, Hockberger PE, Wong RKS. Sustained dendritic gradients of $\mathrm{Ca}^{2+}$ induced by excitatory amino acids in CAl hippocampal neurons. Science 1988; 240: 649-653.

69. Greengard P. Neuronal phosphoproteins, mediators of signal transduction. Molecular Neurobiol 1987; 1: 81-119.

70. Goelet P, Castellucci VF, Schacher S, Kandel ER. The long and the short of long-term memory - a molecular framework. Nature 1986; 322: 419-422.

71. Miller RJ. Protein kinase C: a key regulator of neuronal excitability? Trends in Neurosci 1986; 9: 538-541.

72. Pfenninger $\mathrm{KH}$. Of nerve growth cones, leukocytes and memory: second messenger systems and growth-regulated proteins. Trends in Neurosci 1986; 9: 562-565.

73. Schwartz JJ and Greenberg SM. Molecular mechanisms for memory: second-messenger induced modifications of protein kinases in nerve cells. Annu Rev Neurosci 1987; 10: 459-476.

74. Griffiths T, Evans MC, Meldrum BS. Intracellular calcium accumulation in rat hippocampus during seizures induced by bicuculline or L-allyglycine. Neurosci 1983; 10: 385-395.

75. Olney JW, Collins RC, Sloviter RS. Excitotoxic mechanisms of epileptic brain damage. $I n$ : Delgado-Escueta $\mathrm{AV}$, Ward AA Jr, Woodbury DM, Porter RJ, eds. Advances in Neurology. New York, Raven Press 1986; 44: 857-877.

76. Rothman SM, Olney JW. Excitotoxicity and the NMDA receptor. Trends in Neurosci; 10: 299-302.

77. Sloviter RS. "Epileptic" brain damage in rats induced by sustained electrical stimulation of the perforant path. I. Acute electrophysiological and light microscopic studies. Brain Res Bull 1983; 10: 675-697.

78. Lynch G, Baudry M. The biochemistry of memory: a new and specific hypothesis. Science 1984; 212: 1057-1063.

79. Black IB, Adler JE, Dreyfus CF, Friedman WF, LaGamma EF, Roach AH. Biochemistry of information storage in the nervous system. Science 1987; 236: 1263-1268.

80. Routtenberg A, Lovinger D, Steward O. Selective increase in phos- 
phosylation of a $47 \mathrm{kDa}$ protein (F1) directly related to long-term potentiation. Behav Neurol Biol 1985; 43: 3-11.

81. Morgan JI, Cohen DR, Hempstead JL, Curran T. Mapping patterns of c-fos expression in the central nervous system after seizure. Science 1987; 237: 192-197.

82. Greenberg ME, Ziff EB, Greene LA. Stimulation of neuronal acetylcholine receptors induces rapid gene transcription. Science 1988; 234: 80-83.

83. Gubits RM, Hazelton JL, Simantov R. Variations in c-fos gene expression during rat brain development. Molecular Brain Res 1988; 3: $197-202$.

84. Morgan JI, Curran T. Role of ion flux in the control of c-fos expression. Nature 1986; 322: 552-555.

85. Dragunow $M$, Robertson HA. Kindling stimulation induces $c-f o s$ protein(s) in granule cells of the rat dentate gyrus. Nature 1987; 329: $441-442$

86. Dragunow M, Robertson HA. Localization and induction of c-fos protein-like immunoreactive material in the nuclei of adult mammalian neurons. Brain Res 1988; 440: 252-260.

87. Mody I, Heinemann U. NMDA receptors of dentate gyrus granule cells participate in synaptic transmission following kindling. Nature 1987; 326: 701-704.

88. Sherwin A, Robitaille Y, Quesney L, Reader T, Olivier A, Brière R, Andermann E, Andermann F, Feindel W, Leblanc R, Matthew E, Ochs R, Villemure J, Gloor P. Noradrenergic abnormalities in human cortical seizure foci. In: Engel J, Ojemann GA, Luders HO, Williamson PD, eds. Fundamental Mechanisms of Human Brain Function. New York, Raven Press 1987; 249-258. 